\title{
Peer Group in Social Control of Juvenile Delinquency of Students at Sma Al-Muayyad Surakarta Year $2017 / 2018$
}

\author{
Nafis Nailil, R B Soemanto, Ahmad Zuber \\ Department of Sociology \\ Sebelas Maret University \\ Surakarta, Indonesia \\ nafisnaililh@gmail.com
}

\begin{abstract}
Effective interpersonal relationship requires individual with healthy and balanced personal characteristics. One activity which is developed by an individual in his adolescence is building peer relationship. Positive peer relationship results in academic achievement, while negative peer group relationship creates problems in behavioral patterns. Behavioral problems which are found in adolescence are mostly fights, drug abuse, free sex, and other juvenile delinquencies. It is hoped that positive peer relationship will help preventing individual into juvenile delinquency. This paper explains the role of peer group in social control of juvenile delinquency of students. Case study employing qualitative approach was chosen as the design of the study. Direct interview with some informants became primary data of the data collection method. Moreover, secondary data was taken from school journals and other reliable sources. Findings of the study showed that there were different roles of peer groups in controlling juvenile delinquency from other social controls generally; one reason was due to the educational system which employed Islamic Boarding School system and was oriented towards religious values as well as the sunnah of prophets in creating social solidarity in the peer group as an effort of building social control of juvenile delinquency. Social control of juvenile delinquency built by the peer group was done preventively by preventing such deviant behavior to emerge; and persuasively by persuading others to avoid any restrictions. It can be concluded, then, that peer group has active and positive roles in social control of juvenile delinquency of students.
\end{abstract}

\section{Keywords—peer group; social control; juvenile delinquency}

\section{INTRODUCTION}

Social solidarity exists in a friendship is really influential for the life of an adolescent, especially in creating positive characteristics. Social solidarity is one media which is seen as effective in creating people with care toward others in which each individual keeps reminding to do good things. Social solidarity, especially solidarity in peer group, can be a solution of todays' increasing number of juvenile delinquency. The peer group is key source of emotional knowledge and practice, as peer norms influence students' behavior [1]. That is because peer group solidarity has significant contribution and value to build understanding as well as awareness towards values of togetherness and solidarity which further give positive contribution on the development of adolescent behavior.

Nowadays, educational system in Indonesia is facing lots of complex problems, whether it comes from the educational system itself or those coming outside of the educational settings. The low absorption of graduates in the labor market, low level of educational quality, low motivation to achieve success and other problems become evidences on the existence of gap between adolescents and education. Besides those problems, one problem which nowadays becomes a great challenge, including educational setting, is the increase of social delinquency and moral degradation of adolescents. The level of juvenile delinquency can be influenced by several factors one of the triggers of juvenile delinquency is the influence of peers [2]. There is social delinquency in a little scale in which it is disadvantageous only for himself and social delinquency which is disadvantageous for broader society which further belongs to the category of criminality.

One school in which its students have peer group solidarity who tries to build positive roles to prevent juvenile delinquency to exist is SMA Al-Muayyad which belongs to educational systems employing Islamic Boarding School system. It is why in this era of information and technology which mostly creates individualist characteristics of adolescent, the students can build well relationship and solidarity toward others because the interaction is based on ukhuwahislamiyah. Students of SMA Al-Muayyad are still consistent in building social solidarity with others until today. Nowadays, adolescence social solidarity especially those at the school age, keeps decreasing that they tend to be individualistic and apathetic to other people in their surroundings. Along with the development of technology with its advanced development of smartphone which mostly owned by each adolescent in this era, it helps negative behavior such as ignorance to exist. Other thing that concerns the teachers and parents is that students mostly misunderstand the meaning of solidarity, in which they assume that skipping school together, smoking together, brawling together are parts of solidarity. Intense irritability and mood, high uncontrolled arousal, difficulty carrying a task or activity through to completion, and weak approach or sociability 
predicts poor social skills [3]. That is why the number of juvenile delinquency in Indonesia keeps increasing by years.

Students of Al-Muayyad from years can successfully keep the identity and inherit concern toward others. Peer support is a system of giving and receiving assistance based on tentative principles such as shared responsibility and mutual help among peers [4]. In which concern toward others is nowadays hard to be seen in adolescents. However, social solidarity in peer group at SMA Al-Muayyad is still so strong, especially in preventing juvenile delinquency. Although the school system is based on Islamic Boarding School system which means that most students come from different places and having different cultures, the students can build positive relationship that they assume that they are part of family and that they assume that social solidarity toward each student is part of the implementation of religion and prophet's sunnah. This is seen as interesting by the researcher to dig deeper about the role of peer group in social control of juvenile delinquency of students at SMA Al-Muayyad Surakarta year 2017/2018.

\section{THEORETICAL FRAMEWORK}

In analyzing the problem, the theory which is employed is social control theory proposed by Hirschi [6]. Main idea behind control social theory is that a deviant exists as part of gap in social control. This theory is developed based on belief that each human tends to disobey the rule or has willingness to do violation. That is why, experts in social control seen deviant behavior as logical consequence of someone's failure in obeying the rule. In this context, the theory of parallel social control with theory of conformity [5]; in which there is significant relationship between deviant behavior and individual adjustment process toward values and norms which exist in the society.

One expert who developed this theory is Hirschi [6], who proposed his theoretical propositions, such as:

- That all types of denial toward social rules are results of failure in socializing the society to do conformity toward existing rules or orders.

- Deviant and even criminality or deviant behavior are evidences of failure of conventional social groups to tie up its individual to be conformed like family, school, or educational institutions and other dominant groups.

- Each individual should learn to conform and not doing any deviant behavior or criminals.

- Internal control influences more than external control.

Still talking about his proposition, Hirschi [6] stated at least four main elements in internal social control, which are attachment (affection or participation); commitment (responsibility), involvement (participation), and believe (belief). Those four elements are seen as social bonds whose function is to control individual behavior.

Attachment or affection is source of strength which comes as a result of socialization in individual's primary group (for example family), so that the individual has strong commitment to obey the rule. Related to affection Formm and Schindler in
Horton and Hunt [7] stated that one basic need of human is a need of affection or being loved. Psychiatrists believe that one reason of emotional disturbance, behavioral problem, and even bad physical condition is the absence of affection, which means that there is no warmness, affection relationship in one intimate association society. That there will be rebellion against the child (individual) if preparing for the future focuses only in creating orderliness [8]. Individual needs also tranquility, along with affection given directly or indirectly by relatives or even his maids since it really affects his behavior and personality.

Commitment or responsibility is one element that plays a role in controlling individual behavior [6]. Strong responsibility on rules will help building awareness toward the future. The types of this commitment are those such as awareness that his future will be gloomy if he does deviant actions. It is hoped that by having such awareness, an individual tends to refrain himself to do deviant actions.

Involvement (participation) means that by having such awareness, an individual will act participative and involve in each rule sets by the society. Individual participation intensity toward normative conventional activity will automatically decrease his opportunity to do deviant actions. The higher the awareness toward one society institutions, such as church, school and other institutions, the lower the probability of him to do deviation [7]. Along with that statement, Macklem [9] stated that "if adolescent has good relatives, society, education, and working relationship, they tend to obey the dominant norms" so that by being involved in social system of society, it is said that the opportunity for an individual to do deviant behavior will decrease.

Believe or loyalty and obedience to social norms or rules will finally exist in an individual and it means that selfenforcing exists and that its existence is much stronger [5]. Reckless in Henslin [10] defined belief, here, as trust that the moral action is wrong. In addition, by having that feeling, the possibility for an individual to do deviation will be much lower. On the other side, Laursen [11] stated that belief in this area refers to the norms; the stronger the belief, the lower the possibility to do deviation. For example, an adolescent will not be a member of motorcycle gang and do anarchist actions only when he has awareness and belief that the actions done by motorcycle gang are actions which deviates from the values and norms of the society.

Those four propositions explain that the theory of social control relates each other, Hirschi [6] attachment proposition becomes the strongest source which exists from the result of primary socialization so that an individual has strong commitment to obey the rules. By having that awareness, an individual does participative behavior and are involved in rules that are set by the society. Obedience toward social norms or rules will finally exist in an individual and that means selfenforcing exist and its existence becomes stronger along with the responsibility in being a part of participation so that confidence exists. Those were found in social control of juvenile delinquency of students at SMA Al-Muayyad. The high sense of peer group caring and social solidarity of the students by showing participative behavior and involvement in obeying the social norms along with responsibility toward 
achievement creates confidence to each student. This can explain the proposition of control believe in Hirschi toward social control theory.

\section{FINDINGS AND DISCUSSION}

\section{A. Students' Peer Group Social Solidarity}

The educational system employed by SMA Al-Muayyad Surakarta is senior high school based Islamic boarding school system. That is why the foundation tries to balance formal education which is created by the government with religion education to build religious characters in students. By employing Islamic boarding school system all students have to stay at school during the study period of three until six years long. Students need to adapt to a new environment with new people. In this period, peer group social solidarity is strongly built by students, in which friend becomes relative as substitution of family.

Social solidarity which was built in students' peer group was organic solidarity; in which it was built according to kinship among Muslims who has the same line of descent who is the prophet of Adam. As a result, the relationship was eternal, which meant that though the students had become alumni, they still tied in a bond of alumni santri whose ukhuwah was still being well kept. While living in the boarding school, interdependence exists among others due to situation and condition since all students were separated from family. That was why affection and love were built by actively participated in helping others especially in learning, surviving, obeying rules, praying, and struggling to accomplish the goals

\section{B. Types of Students' Juvenile Delinquency}

Juvenile delinquency is a type of deviation of rule which is done by person at the age of 13-17 years old. Usually juvenile delinquency is a form of self-actualization of adolescent for his existence to be recognized in the environment where the adolescent lives. Most adolescents do not realize that their action contradicts to the norms and values and that it might harms others. Since the school is based on Islamic boarding school system, some juvenile delinquencies done by students were as follows:

1) Violation of discipline: What it meant by violation of discipline here was that the student did not obey the rule such as waking up late, so that he/she did not join JamaahSubuh, being late for early study (mengaji), so that he/she was late to school. At schools, many students were indiscipline since they wore the wrong uniform yet thinking that it was such a normal action. At classroom, some students were so sleepy, even sleeping during the teaching and learning process, some of them did not do the task given by their teacher too. During the teaching and learning process, students showed less discipline in time; while the break was over, they were still outside of the classroom, such as canteen or boarding room and even some male students did not go back to class. Moreover, some violations were also found such as bringing handphone and other electronic devices which resulted in lowering the achievement.
2) Violation of ethics: Violation of Ethics which were done by students of SMA Al-Muayyad were those such as being impolite in speaking which mostly done by male students; showing no respect to teachers, that they played during teaching and learning process and ignoring teacher's advices to focus on the subject being learnt; having relationship with female students; and playing which disturbed madrasah's activity.

3) Violation of aesthetics: Violation of aesthetics here were those such as improper behavior which do not reflect the behavior of santri that they had to behave religiously since they live in an Islamic boarding school. Moreover, there were other improper actions such as dying the hair especially male students and opening the veil (hijab) done by female students; improper dressing such as wearing tight jeans which was done by male students and wearing tight shirt above the buttocks for female students. Besides, most male students smoked at the school environment. In todays' era of information and technology, where social media becomes a need to do selfactualization by uploading photos as well as captions, students did that action too. Unfortunately, students uploaded negative contents such as inappropriate words or photos.

\section{The Role of Peer Group Solidarity as Social Control of Students' Juvenile Delinquency}

1) Preventive social control: In doing preventive social control of juvenile delinquency of students at SMA AlMuayyad, the role of peer group was the same as the role of a family to prevent its children to do deviation, to stay on the right track, to give guidance as well as suggestion. By having responsibility toward each other, the affection toward friend becomes higher. So that in order to prevent deviation from values and norms, peer group will participate in social control by doing their own way such as giving real example like exchanging thoughts in a form of peer discussion, and holding activities containing positive and religious values. Those were done to prevent opportunities for students to do unbeneficial things which led to juvenile delinquency to happen.

2) Persuasive social control: In doing persuasive social control of juvenile delinquency of students at SMA AlMuayyad, the role of peer group was as partner who worked together in an effort to accomplish the goals. By building social solidarity, peer group tried to motivate each other in pursuing success, reminding others when they did deviation, asking to do positive things in their spare time, asking to not disobey the rule whether they were in school or in boarding room, and guiding each other to be on the right way by obeying the values and norms; so that the phenomenon of juvenile delinquency of students at SMA Al-Muayyad could be prevented and overcome without doing excessive actions.

\section{CONCLUSION}

Peer group is a group of adolescents consisting of individuals who have the same age and social status. By having emotional bond in the peer group, benefits and positive influence will arise. So that peer group can be defined as group 
consisting of peers who have strong emotional bond and that they can exchange thoughts and experiences in order to create changes and development in their social and personal life. This strong emotional bond will help creating strong solidarity in the peer group. So that the role of peer group in social control of juvenile delinquency of Al-Muayyad students is really active and positive through preventive and persuasive approach. At last, social control of juvenile delinquency through peer group which was done persuasively was thought as more beneficial since it is in line with the development of psychology of adolescent who are in the phase of learning and socializing with peers instead of family.

\section{REFERENCES}

[1] Bronson, M. B., The Right Stuff : selecting play material to support development. Washington: National Assosiation for the Education of young Children. 1999
[2] Thornburg D., Development in adolescence second adition, California:Brook cole publishing Co. 1982.

[3] Sanson. The Science Of Prevention For Children An Youth. Australian: Institute of family studies. 2011

[4] Miller, J. B. and Stiver, I., The Healing Connection.Boston, MA Beacon Press. 1998.

[5] Cowie, H, Wallace, P., Peer Support in Action : From Bystanding to Standing By. London: Sage Publications. 2000.

[6] Hirschi, T., Causes of Deliquency. Barkeley: University of California Press. 1969.

[7] Paul B. H., and Chester L. H., Ciri-ciri Perilaku Menyimpang Pada Remaja. Jakarta, 1996.

[8] Carr, R. A., Theory and Practice of Peer Counseling. Ottawa :Canada Employment and Immigration Commision. 1981.

[9] G. L. Macklem, Practioner's Guide to Emotion Regulation In SchoolAged Children. Springer, 2008.

[10] Henslin M. J., Sosiologi dengan Pendekatan Membumi,(terjemahan kamanto sunarto) Jilid 2. Jakarta : Erlangga. 2006.

[11] Laursen, E. K., Rather Than Fixing Kids- Build Positive Peer Cultures. Reclaiming Children and Youth. 14. (3).137-142 (ProQuest Education Journals). 2005. 